\title{
How Formal and Informal Institutional Environments Affect the Way Greenpeace Fights Genetically-Modified Organisms in Europe and the United States
}

\author{
Stephen R. Luxmore \\ Saunders College of Business, Rochester Institute of Technology \\ E-Mail: sluxmore@saunders.rit.edu \\ Clyde Eiríkur Hull \\ Saunders College of Business, Rochester Institute of Technology \\ E-Mail: chull@saunders.rit.edu
}

\begin{abstract}
We applied institutional theory to examine the effect of differences in institutional pressures on strategic decisions of a non-profit non-governmental organization, Greenpeace, in its fight to stop the use of genetically-modified organisms. The effects of differences in institutional pressures were examined through examining differences between the United States and the European Union as well as between two European nations, France and Spain, in Greenpeace's strategy. We suggested that formal and informal institutional pressures influence strategic decision-making in Greenpeace's independent national units. We proposed that the US differs from the EU in both formal and informal institutional environments, Spain and France differ in the informal dimension, and these differences are reflected in Greenpeace's strategies. We also argued that Greenpeace exemplifies the successful use of a transnational strategy and discussed whether non-profits may be better able to adopt a transnational strategy than are for-profits.
\end{abstract}

Keywords: Institutional theory, European Union, United States, Non-governmental organization, Greenpeace

\section{INTRODUCTION}

Social enterprises are becoming increasingly important and continue to erase the boundary between non-profit and for-profit (Carraher, Welsh, \& Svilokos, 2016). Technology facilitates the blurring of these boundaries and the rise of social enterprise 
by enabling crowdfunding, which can range from highly profit-oriented funding to donation-based crowdfunding appropriate for non-profits (Kshetri, 2015). As nonprofits and for-profits find themselves in competition more frequently, it is increasingly important for businesses to understand the drivers of non-profit behavior (Eesley, Decelles, \& Lenox, 2016). Some researchers have paid attention to differences between non-profits and for-profits in strategic decision-making (e.g., Hull \& Lio, 2006; Nugroho, 2011 while other have focused on multinational non-profits in the international management context (Rost \& Graetzer, 2014). However, too little attention has been paid to how institutions, particularly government (formal institutions), affect non-profit use of strategies commonly studied in the business context (Bloodgood, Tremblay-Boire, \& Prakash, 2013; Frumkin \& Andre-Clark, 2000). We address this gap as well as the premise that informal institutions interact with the formal ones to affect non-profit strategies. Finally, using the example of Greenpeace, we consider how well a multinational non-profit can respond to varied local institutional pressures, that is, how well, in effect, it can pursue a transnational strategy.

Institutional theory considers how societal norms, rules, and practices form institutional pressures and place pressure on organizations, shaping the way they operate within these societies along with the strategic options that are available to them (Almadi, 2016; Hitt, Ahlstrom, Dacin, Levitas, \& Svobodina, 2004; Lu, Xu, \& Liu, 2009; Meyer, Estrin, Bhaumik, \& Peng, 2009; Ren \& Jack, 2014). These pressures can be divided into formal and informal: the formal government regulatory context and the more informal aspect of culture and norms. While much of the extant literature has investigated institutional influences in the context of transitional economies where institutions are in transition, yielding more dynamic results, institutional theory should also apply to developed nations (Peng, Sun, Pinkham, \& Chen, 2009). As the recent election in the United States illustrates, institutional pressures can shift dramatically in developed nations as well. Some empirical support has been found to suggest that an effectively-managed non-profit should be ready to reallocate resources in response to these pressures, although non-profits have been argued to be more constrained compared to for-profits in their strategic decision-making (Hull \& Lio, 2006; Hinz \& Ingerfurth, 2013). Ownership structure matters, as institutional pressures affect stateowned and non-state-owned enterprises differently (Ren \& Jack, 2014).

Thus, in this study, we applied institutional theory to non-profit strategy in industrialized nations using the example of Greenpeace, a non-profit organization. Nonprofit behavior and strategy are significant issues in business, regardless of whether the non-profits are competing with for-profits directly or trying to constrain their behavior in other ways (Doh \& Guay, 2006; Kourala, 2010; Kourula \& Laasonen, 2010; Luxmore \& Hull, 2011; Taysir \& Taysir, 2012; Teegen, Doh, \& Vachani, 2004; Vachani, Doh, 
\& Teegen, 2009), as non-profits are important players in global markets (Kourala, 2010). Differences between the constraints on non-profits and those on for-profits may affect responses to similar pressures (e.g., Hull \& Lio, 2006; Davis, Marino, Aaron, \& Tolbert, 2009). In assessing the effects of formal and informal institutional pressure on Greenpeace, we intended to address this confusion.

We looked specifically at Greenpeace's opposition to genetically modified (GM) crops and food. Research on the GM controversy has emphasized the strategies of GMproducing firms, such as Monsanto, and has addressed the effect of regulatory and civil society on firm strategy (c.f., Luxmore \& Hull, 2010; Schrempf-Stirling, Palazzo, \& Phillips, 2016; Soule, 2003). By studying Greenpeace, which encourages all forms of environmental responsibility across multiple national boundaries, we are contributing to the corporate environmental responsibility literature that has called for more research that transcends national borders (Holtbrügge \& Dögl, 2012). This paper examines how differences in institutional settings, both within Europe and between Europe and the US, affect Greenpeace's strategies, as reflected in its resource allocations. Our study rests upon the premise that institutional theory applies to developed economies and to nonprofit organizations. Thus, we developed the following research questions:

(1) How do formal and informal institutional differences affect non-profit resource allocation in different countries?

(2) Does Greenpeace, in its crusade again GMOs, present a good model for other organizations to follow?

We expected that the differences in institutional environments not only between the US and the EU but also between two neighboring EU member nations would generate predictable and significantly different organizational behavior in each of these industrialized economies. These differences in the implementation of the Greenpeace campaign against GM crops and food by different national units or branches may then serve as a model for other multi-national organizations.

One dimension of the institutional setting is the formal regulatory environment, which is different in the United States and the European Union in terms of the decisionmaking processes and outcomes regarding the planting, harvesting, and consumption of GM crops (Doh \& Guay, 2006). The other institutional dimension is the informal one, concerning culture and normative beliefs. US attitudes regarding the safety of technology-derived GM crops and attitudes toward GM food products and food in general differ from those in Europe (Isaac, Perdikis, \& Kerr, 2004). They may also 
differ between the two EU nations in this study, France and Spain, which are similar in many respects, but different in informal institutional pressure. We used institutional theory to develop and examine predictions concerning the effects of institutional differences in these three settings on Greenpeace's strategic behavior.

We briefly review institutional theory in the context of nonprofit organizations and subsequently provide an overview of the Greenpeace organization. Next, we discuss institutional environments in the EU and the US and their application to the case of Greenpeace's anti-GMO campaign. Finally, we present the methodology, analysis, and results, followed by our discussion and conclusions.

\section{Institutional Theory and Nonprofits}

Institutional theory, or the institution-based view of strategic management (Lu et al., 2009; Peng et al., 2009), focuses on how environmental contexts in which organizations operate, such as government regulation and popular perception, affect their strategic options and behavior (Al-Shammari, 2012; Finegold, Klossek, Nippa, \& Winkler, 2010; Peng, 2002, 2014). In this context, the term "institution" can be understood to mean highly resilient social structures (Scott, 2008), such as the "blogosphere" and other informal means of information dispersal, which have evolved into significant institutions. How the EPA regulates pollution, for example, would be a formal institutional pressure in the United States. Understanding the interactions among organizations, non-profit and otherwise, is essential for understanding strategic choice (Peng, 2003, 2014). Institutional theory has been shown to explain the choices of nonprofits in at least some settings (Berrone, Gelabert, Massa-Saluzzo, \& Rousseau, 2016; Garrow \& Hasenfeld, 2014). Institutional pressures could also serve to explain unexpected results of studies of non-profit behavior in a specific industry in a geographically confined region, such as that of Davis et al. (2009) in which non-profit nursing homes in Florida were found to be more strategically competitive than their forprofit competition.

North (1990) and Scott (2008) framed the institution-based view along formal and informal dimensions that set the context for organizations. The context is a 'set of fundamental political, social, and legal ground rules that establishes the basis for production, exchange, and distribution' (Davis \& North, 1971, as cited in Parkhe, 2003, p. 307). The formal institutional dimension includes the political process from which the rules and regulations originate (Hillman \& Keim, 1995) and the enforcement of the rules (Meyer et al., 2009). The informal institutional dimension includes acceptable behaviors, customs, and internalized beliefs of social actors, and both formal and informal institutional pressures may constrain strategic choice and behavior (Almadi, 2016; Hiatt \& Park, 2013; Peng 2002, 2003, 2014). 
Institutional theory has traditionally focused on emerging nations (c.f., Wu \& Ying, 2016), arguing that formal institutions operate predictably in developed nations, reducing institutions to a nearly invisible role. However, institutional differences between developed and developing nations may be smaller than predicted (Tantawi, O'Shaughnessy, Gad, \& Ragheb, 2009). Differences between developed nations may be significant, and formal and informal institutions in developed economies can still work differently and should be studied (Peng et al., 2009). Bloodgood et al. (2013) demonstrated that formal institutions regulate non-profits differently across developed economies, and Frumkin and Andre-Clark (2000) showed a significant effect of a change in formal regulations on non-profit behavior. Our study expands upon their findings by examining informal institutions as well.

The institution-based approach suggests that institutions reward and punish different behavior differently and that participants behave rationally in response, seeking to avoid the punishments and earn the rewards (Peng et al., 2009). Although humans cannot be perfectly rational (Cheng \& Liao, 2017; Simon, 2013), players merely need to be relatively rational, given the bounds on their rationality. Institutions, in other words, focus national attention in certain directions, and what is important under one set of institutional norms is unimportant under another.

This focusing of attention on certain topics with certain attitudes is called cognitive bias (Cheng \& Liao, 2017; Simon, 2013). Because national institutions, by definition, influence national cognitive biases, the bounded rationality perspective (Cheng \& Liao, 2017; Simon, 2013) supports Peng et al.'s (2009) proposition that formal and informal institutions, as structures that reward and punish different behavior, influence strategic decision-making in developed nations. The rules of thumb that managers apply are likely to match the formal and informal institutional pressures, regardless of whether the managers are aware of these institutional pressures, as they will have absorbed their frames of reference both from other managers who have been successful in dealing with these institutional pressures and from the culture that developed the informal and informal pressures. Peng et al. (2009) called for institution-based research to address public policy issues and firm adaptation to institutional changes. Consistent with their call, we consider public policy decisions regarding the GM crops and food and the ways in which those decisions affect institutional environments and examine changes to organizational decision-making as adaptations to changes in institutional environments.

Formal and informal institutional environments depend on each other, as laws affect behavior, behavior affects culture, and culture shapes laws and their enforcement. 
Forms of government, the type and operation of government agencies, and corporate and nongovernmental organizations' methods used to affect policy differ as a result of informal institutional variation (Hillman \& Keim, 1995; Kourala, 2010). Thus, policy and regulatory changes shape the formal institutional environment, and they are affected by the existing political constructs and informal institutional settings. Greenpeace's ability to alter formal and informal institutional contexts may be different in the United States and the EU due to contextual issues, again suggesting that the strategies of the national units differ. The following section discusses Greenpeace, and the specific formal and informal frameworks are discussed in the subsequent section.

\section{Greenpeace}

Greenpeace is an international non-profit organization consisting of a coordinating body, Greenpeace International (registered as Stichting Greenpeace Council) in the Netherlands, and a network of over 30 national and regional Greenpeace organizations, the majority of them residing in Europe. These local groups have considerable latitude in setting their own agendas. Greenpeace International coordinates global policy and strategy toward the goal of conserving nature and ensuring 'the ability of the earth to nurture life in all its diversity' (Greenpeace International, 2018). As such, it allocates resources to international goals under the guidance of representatives of various national chapters. Greenpeace's efforts can thus be observed at the national level, at the international level (Greenpeace International), and global level (the combined efforts of the national branches and the international body). Greenpeace's global governance structure 'reflects fundamental respect for global democratic principles and the need to maintain a high level of internationalism and coordination' (Greenpeace International, 2018). The International organization monitors financial and strategic performance globally, facilitates planning and decision-making processes, and coordinates and implements global campaigns. These campaigns can be considered marketing campaigns in the sense that they are coordinated efforts to persuade a target audience to change its behavior, though both academics and practitioners have generally a poor understanding of marketing in non-profits (Pope, Isely, \& Asamoa-Tutu, 2009). Representatives from each office attend the Greenpeace International Annual General Meeting to discuss strategic issues and elect members of the board of directors. Additional meetings are held to discuss campaign priorities and policies and operating relationships among units. Additionally, the international campaign director meets with national and regional counterparts (Greenpeace International, 2018).

Despite this coordination and integration, each national or regional office is expected to have its own autonomous localized governance structure representing its nation or region. National and regional units work with the International Council to prioritize global campaigns, and each unit is required to 'actively carry out at least two 
different campaigns in two different campaign areas (as defined by Greenpeace International) unless otherwise agreed in the organizational development plan' (Greenpeace International, 2018). The national and regional offices have discretionary authority over which campaigns to fund. Thus, they determine the amount of resource allocation to a given campaign that can be used to indicate a national unit's strategic priorities.

Greenpeace has six global campaigns (note: the names and composition of each campaign may change across years): (1) climate change, (2) forests, (3) oceans, (4) agriculture, (5) toxic pollution, and (6) nuclear. In their aggregated financial statements (Greenpeace Worldwide), forests, climate change, and nuclear and disarmament campaigns have received the highest level of funding during the timeframe that agriculture (genetic engineering) received its highest funding levels. This study focuses on the agriculture campaign, which includes the goal of banning GMs (see Table 1 for overview of funding this campaign). This goal has remained constant since it was first addressed in the 1996 Annual Report: 'Greenpeace is campaigning to halt the uncontrolled introduction of genetically-modified foods into our shops' (1997: 9). The anti-GMO campaign has included lobbying and presentations at government organizations, supranational organizations, and conferences to protest and pressure farmers and companies in the food industry to cease GM use.

\section{Institutional Environments in the EU and US}

We propose five predictions based on institutional theory. The predictions rest on the assumption that Greenpeace, like an effective transnational, is responsive to both formal and informal institutional environments in developed nations. Multinational entities (MNEs) vary their strategic direction in a manner consistent with institutional differences in local markets (Peng, 2003). Tang and Hull (2012) found that institutional differences between China and the US caused firms with similar characteristics (e.g., degree of entrepreneurial orientation) to select different strategies, including allocating their resources differently. Wu and Ying (2016) found similar results in a study of auditors in China, while Wales, Shirokova, Sokolova, and Stein (2016) found that institutional pressures in Russia affect the same characteristics that Tang and Hull (2016) examined. Chen, Yang, Hsu, and Wang (2008) found formal and informal institutions to be the most pervasive factors in entry-mode choice into the China market. Other studies reported similar results for entry-mode choice and market access (Meyer et al., 2009), strategic alliance partner selection (Hitt et al., 2004), and transaction choice (Zhou \& Peng, 2010). Kourala (2010) found that both institutional differences and non- 
profit behavior influence MNE behavior. Tantawi et al. (2009) found striking institutional similarities with respect to environmental issues between Egypt and developed nations, suggesting again that factors other than 'developedness' drive the applicability of institutional theory.

In the non-profit sector, van Leeuwen and Wiepking (2012) observed crossnational differences in campaign fundraising consistent with specific national institutional characteristics, such as trust, state structure, and fundraising regulations. Bloodgood et al. (2013) suggested that approaches to non-profit regulation differ across developed economies. Non-profits might not respond to regulations the same way as MNEs do, given that MNEs want access to markets while non-profits' motivations are different (Hull \& Lio, 2006). To the extent that the regulations are effective, non-profits that want to operate in a nation must respect the regulations that are enforced there. With respect to informal institutions, prosocial behavior (voluntary behavior that benefits others or society as a whole) varies along several cultural dimensions (Luria, Cnaan, \& Boehm, 2015), which suggests that a potentially similar result might emerge for non-profits, which are, at least in theory, embodiments of prosocial behavior. Consistent with Hull and Luxmore (2007), Isaac and Kerr (2003), Peng (2002, 2003), and Peng et al. (2009) who found that institutions affect strategic choices, such as resource allocation, we expected to find significant differences in resource allocation to anti-GM campaigns of the US national units and the two Greenpeace national units in the European Union.

France and Spain may, by virtue of being in the EU, share similar formal institutions. However, as discussed in the next section, they are culturally different, and as such, they have different informal institutional environments, specifically with respect to GMOs. We thus expected to find significant resource allocation differences between the national units in France and Spain. We present our specific predictions in the context of the formal and informal institutional environments.

\section{Formal Institutional Pressures}

The risk assessment and management process is the primary formal institutional consideration for GM crops. The original approach in both the US and the EU was intended to emphasize science-based consideration in regulatory decisions concerning advanced technologically developed products and to diminish the role of non-scientific aspects of the process (Isaac \& Kerr, 2003). This approach aimed to decouple regulatory decisions from politics, creating a transparent and consistent decision process. Isaac and Kerr (2003) identified this approach as the scientific rationality perspective. The science behind the scientific rationality perspective has been questioned, however (Séralini et al., 2009), leading us to wonder whether the perspective should be labeled as the "financial rationality perspective." 
Soule's (2003) study of the introduction of GMs in agribusiness and Kysar's (2004) analysis of genetic engineering processes provide a comprehensive description of the formal institutional framework in the US. Three government units - the FDA, the EPA and the Department of Agriculture - are responsible for the administration of the regulatory process policy developed under the Reagan administration (Kysar, 2004; Saigo, 2000). The EPA assesses environmental risks, the FDA evaluates GMs for human consumption, and the Department of Agriculture assesses GMs in agricultural production (Hiatt \& Park, 2012; Kysar, 2004). Soule (2003) emphasized the rigor of the oversight of the framework and the analysis of environmental risk and human health concerns. However, both the administration of the standards (Kysar, 2004; Séralini et al., 2009) and scientific rationality itself (Hull \& Luxmore, 2007) have been criticized.

The US has used the scientific rationality approach consistently. This approach has several implications, including the primacy of technological progress; recognition of risk, including hypothetical but not speculative risk; acceptance of substantial equivalency of the product (emphasizing the outcome/product over the process or technology); minimization rather than elimination of risk; and a scientific rather than a social interpretation of the precautionary principle (Isaac \& Kerr, 2003). Kysar (2004) elaborated on the precautionary principle and substantial equivalence, claiming that the precautionary principle is invoked to consider environmental and health risk in advance of knowing the magnitude of the risk or evidence of harm done. On the other hand, the substantial equivalence aspect of the process assesses the equivalence of the 'composition and other tangible characteristics of the modified organism and its conventional counterparts' without considering the genetic modification process (Kysar, 2004: 557). Isaac et al. (2004) identified human health, safety, and biodiversity as the determining regulatory factors in the scientific rationality philosophy, excluding moral and economic concerns. However, Séralini et al. (2009) noted that the science based on which decisions permitting GMOs to move forward were made was highly questionable and obscured from the public until years after the decisions were made. In the US, the farm industry has considerable influence over the approval process at the Department of Agriculture, and this power increases significantly in the face of pressure from NGOs, such as Greenpeace (Hiatt \& Park, 2012). Thus, again, it could be argued that the "scientific rationality" approach is actually the rationality of entrenched business interests rationally pursuing their own financial interests, regardless of either scientific or social merits.

The regulatory structures in the EU and the US were initially similar (Soule, 2003). Scientific expertise was considered fundamental to EU integration to keep national 
regulations from undermining pan-EU trade (Levidow, Carr, \& Wield, 2004). The emphasis on science was believed to create an objective approach to regulatory decisions. However, in 1999, some EU member nations withdrew their support of the EU scientific rationality approach, stalling the regulatory decision process (Levidow et al., 2004; Soule, 2003; van Schendelen, 2003). Precaution became the watchword (Levidow et al., 2004), and the process became more politicized as more voices began to be heard in the process. An alternative interpretation is that the EU turned to a "social rationality" approach that put much-needed emphasis on social needs and concerns (Hull \& Luxmore, 2007). Both interpretations agree that the new approach was much more conservative or precautionary.

The EU's new approach championed a broad interpretation of the precautionary principle while the European Commission's original approach favored a narrow interpretation (Levidow et al., 2004) consistent with the scientific rationality (or financial rationality) philosophy that emphasizes caution over precaution (e.g., not accepting that tobacco causes cancer for decades after it has been proven or not accepting that GMOs carry a risk of chronic and subchronic diseases; Séralini, et al., 2009) and the role of science or a reasonable facsimile thereof in regulatory decisions.

The EU's new, broad interpretation of precaution is more consistent with social rationality (Isaac \& Kerr, 2003; Hull \& Luxmore, 2007), requires stakeholder involvement, emphasizes precaution over caution, allows speculative risk (such as speculating that tobacco might cause cancer even though it hasn't been officially proven), and considers social and moral issues in the regulatory process. The EU rules implemented in 2003 opened the process to public input, and they are substantially different from more closed US rules as well as original EU rules (Kysar, 2004). The structure and operations of the EU continue to encourage the participation of numerous stakeholders, including non-profits, in policy formation (Doh \& Guay, 2006) and in MNE behavior (Kourala, 2010).

Thus, though the formal institutional environments in developed economies of the US and the EU were similar in the early stages, they have diverged and are now substantially different. The regulatory approach in the EU transitioned from a scientific rationality system in the early part of the 1990 s to a de facto social rationality approach by 1999 and a formalized social rationality approach in the $21^{\text {st }}$ century (Levidow, Murphy, \& Carr, 2007). The precautionary principle, or social rationality approach, of the EU includes the regulation of not only the product, as in the US, but also the technological process (Guehlstorf \& Hallstrom, 2005). Additionally, the EU, unlike the US, requires GMs to be proven safe prior to their introduction (Doh \& Guay, 2006).

\section{Predictions Concerning The Formal Institutional Environment.}


Because we are focusing on one multinational NGO rather than on a large number of NGOs, we present predictions rather than hypotheses to be tested in the case of Greenpeace.

The formal institutional environment was in transition in the EU during the late 1990s to the mid-2000s, while it was stable in the US. Regulation in the US is based on scientific rationality principles, limiting the scope of risk assessment and requiring the participants to possess scientific expertise of GM products (Isaac \& Kerr, 2003; Luxmore \& Hull, 2010). In Europe, the regulatory process changed from a scientific rationality to a social rationality approach that is open to input from all stakeholders and considers a broad scope of risk factors, including social ones (Isaac \& Kerr, 2003). This transition allowed for speculative risk as well as scientific evidence to be considered. The formal institutional environment in the EU is now more favorably inclined to influence by civil society due to the structure of the EU regulatory system and the social rationality approach to regulation.

The EU approach not only encourages participation by non-profits, such as Greenpeace, but also lets them affect public policy decisions directly. In the United States, non-profits are not formally included in the regulatory decision-making process, although they can, like anyone else, submit comments to such bodies as the FDA or the EPA on proposed regulations (Doh \& Guay, 2006). Hence, non-profits have limited power to affect public opinion and firms directly. We expect that these formal institutional differences will be reflected in Greenpeace's strategic behavior. Because most national and regional members of Greenpeace International are European, we expect that Greenpeace International and Greenpeace Worldwide will behave relatively consistently in France and Spain, and that Greenpeace's behavior in the US will be different. In Europe, formal institutional pressures welcome and encourage social and non-profit input while in the United States, they do not. In the arena of GM, unlike the arenas in which some of its other campaigns focus, the battles are largely regulatory and thus government-focused, and informal institutions that favor GMOs are relatively well-established (Doh \& Guay, 2006). Gaining legitimacy for a new cause and influencing formal and informal institutions is best done under circumstances of weak or missing institutions, not strong, well-established ones (de Lange, 2016). Thus, we expect that Greenpeace will allocate significantly fewer funds to this campaign in the US than outside the US:

Prediction 1a: Greenpeace France will allocate a significantly greater percentage of its resources to the anti-GM campaign than will the Greenpeace in the United States. 
Prediction 1b: Greenpeace Spain will allocate a significantly greater percentage of its resources to the anti-GM campaign than will the Greenpeace in the United States.

Prediction 1c: The United States Greenpeace will allocate a significantly smaller percentage of their resources to the anti-GM campaign than will Greenpeace International.

Prediction 1d: The United States Greenpeace will allocate a significantly smaller percentage of their resources to the anti-GM campaign than will Greenpeace Worldwide.

\section{Informal Institutional Pressures}

More EU residents than US residents oppose GMOs (Doh \& Guay, 2006; Isaac et al., 2004; Legge Jr. \& Durant, 2010; Soule, 2003). A review of public opinion surrounding GMOs during the mid to late 1990s (Soule, 2003) indicates that:

- more Europeans opposed GM foods than supported them

- more US residents supported than opposed GM foods

- more Europeans believed that environmental organizations would provide more truthful information about GMOs than would farming organizations, government, or business

- in the US, an overwhelming number of respondents reported strong trust in the USDA, the FDA, and business regarding biotechnology

Doh and Guay (2006) found substantially stronger support for GM cultivation and foodstuffs in the US than in Europe. Isaac et al. (2004) described North American consumers as indifferent to the introduction of GMs while describing Europeans as concerned. Wootliff and Deri (2001) reported that Europeans trust non-profits over businesses, government, and media while US citizens trust businesses over government, non-profits, and media (in descending order). Europeans have less favorable attitudes toward new technology than do US citizens who embrace technological advancement, and Europeans emphasize an aesthetic attitude toward food, in contrast to the more utilitarian US attitude (Runge, Bagnara, \& Jackson, 2001).

\section{Predictions Concerning the Informal Institutional Environment}

Europeans demonstrate a greater distaste for and distrust of GM products than do citizens of the US. If the formal institutional environments were similar, then strategic behavior differences could be due to informal pressures. Even in the presence of formal institutional differences, informal institutional pressures could still be influential. We expect the levels of funding for Greenpeace's anti-GM campaign in different environments to differ based on the local attitudes toward GM crops and foodstuffs. The attitude toward GMs is friendlier in the US than in the EU, and the informal level 
of trust in non-profits is higher in the EU than in the US. We predict that formal and informal institutional differences between the European Union and the United States will put parallel pressure on local Greenpeace units. Those in the US will be discouraged from wasting money on the losing game of anti-GM while those in the EU will be encouraged to participate in a much more successful anti-GM campaign. To identify the differences in the effects of these pressures, if any, we turn to a situation where the formal institutional pressures are the same but the informal institutional pressures are different.

France and Spain are both members of the European Union; thus, it can be argued that they face similar, if not identical, formal institutional environments. However, their informal institutional environments are very different. According to the Hofstede Centre (2018), the French are more individualist and higher on power distance (meaning they are more accepting of hierarchies with power focused near the top) compared to Spaniards, and the French are more long-term oriented than are Spaniards. As a reflection of this long-term orientation, France is known for being one of very few nations to formally regulate its language, reflecting national pride in the purity of "France." If GM crops can be portrayed as defiling that purity, a strong anti-GM response would be expected. Alternatively, one might argue that the French are more likely to look at long-term consequences than are the Spanish, while both are more likely to do so than people in the United States, where individualism is high, uncertainty avoidance is low, and long-term orientation is the lowest measured trait (Hofstede Centre, 2018). Although citizens of Spain and the US may be no less proud of their respective nations, that pride is not necessarily linked to the long term or on environmental issues related to GM crops or foods. Furthermore, France exports more than twice as many agricultural products as Spain (OEC 2018a, 2018b), so potentially, it has more reasons to care about the purity and its reputation for purity of its agricultural products. The finding (Ioannou \& Serafeim, 2010) that French firms average .72 on a standardized measure of environmental responsibility and Spanish ones average .64 (US ones average .37) supports the above-stated arguments. It suggests that the informal institutional environment in France is more strongly supportive of environmental matters in general than the corresponding one in Spain. The effects of the differences in informal institutional environments between the US and the EU cannot be measured in this study separately from the formal differences. However, we can predict differences caused by informal institutional differences between France and Spain:

Prediction 2: Greenpeace France will allocate a greater percentage of its resources to the anti-GM campaign than will Greenpeace Spain. 
Because of the similarity in formal institutional environments between the two nations, any difference found here should be attributable to differences in informal environmental environments.

\section{RESULTS AND DISCUSSION}

The data were gathered from the annual reports of Greenpeace International and the respective national Greenpeace units. Greenpeace reported expenditure on the thencategorized biodiversity campaign in its 1994 and 1995 annual reports but did not mention GM products until 1996. In 1998, the annual report changed the campaign's name from "biodiversity" to "genetically modified organisms." Resource allocation data were collected beginning with the 1998 annual reports. Financial data for Greenpeace USA, France, Spain, Greenpeace International, and Greenpeace 'Worldwide' were taken from their annual reports. The Greenpeace International financial report was derived from the financial reports of Stichting Greenpeace Council and other affiliated Greenpeace organizations but not from the Greenpeace national offices. Greenpeace 'Worldwide' financials were the aggregated financial data for the national/regional units, as reported to Greenpeace International (Greenpeace International, 1997). The expenditures on each campaign were summed, and the percentage of expenditure on the anti-GM campaign calculated. Greenpeace International expenditures on the anti-GM campaign are available as far back as 1997 , while 2001 was the first year for which comparable national unit data are available (data from Spain from 2001 and 2003 are also missing).

The data for Greenpeace International provide the budget allocation decisions of the International unit and reflect the global policies and strategic direction of the Greenpeace coordinating body. Greenpeace International also reports the aggregate data for all national units by campaign and thus provides the average worldwide budget allocation. These data exclude Greenpeace International budget information. Data are also available for the national units of France, Spain, and the United States. The US unit reports its budget by campaign for two purposes: direct campaign action, which is USA, Inc., and education and research efforts, which is USA Fund. Rather than choosing one to represent the US, we evaluated Predictions 1a, 1b, 1c, and 1d using the data from both US units for more robust findings.

In the initial campaign year, GM received a relatively low percentage of the budget. Greenpeace International allocated 4.05 percent of its budget to this campaign in 1997 while worldwide, the national and regional offices allocated 2.15 percent of their combined budgets. The remaining budget allocations are shown in Table 1 . The campaign reached its peak allocation in 2004, with 16.52 and 18.68 percent being allocated to Greenpeace International and Worldwide financials, respectively. 
Table 1 Resource allocation to anti-GM campaign (percent of total campaign budget)

\begin{tabular}{lcccccccccccc}
\hline & $\mathbf{1 9 9 7}$ & $\mathbf{1 9 9 8}$ & $\mathbf{1 9 9 9}$ & $\mathbf{2 0 0 0}$ & $\mathbf{2 0 0 1}$ & $\mathbf{2 0 0 2}$ & $\mathbf{2 0 0 3}$ & $\mathbf{2 0 0 4}$ & $\mathbf{2 0 0 5}$ & $\mathbf{2 0 0 6}$ & $\mathbf{2 0 0 7}$ & $\mathbf{2 0 0 8}$ \\
\hline International & 4.05 & 8.51 & 6.78 & 8.33 & 9.87 & 10.49 & 11.52 & 16.53 & 12.78 & 11.21 & 13.92 & 8.75 \\
World Wide & 2.15 & 7.61 & 8.99 & 14.98 & 14.88 & 14.55 & 17.43 & 18.68 & 15.63 & 12.27 & 10.41 & 8.65 \\
France & & & & & 11.45 & 12.32 & 13.28 & 15.43 & 12.78 & 14.61 & 14.25 & 15.42 \\
Spain & & & & & & 12.43 & n.a. & 12.26 & 10.71 & 8.25 & 9.57 & 9.87 \\
USA, Inc & & & & & & & 8.64 & 0.0 & 0.0 & 0.0 & 0.0 & 0.0 \\
USA, Fund & & & & & & & 18.29 & 2.04 & 0.0 & 0.0 & 0.0 & 0.0 \\
\hline
\end{tabular}

In the US, the GM campaign has received zero budget allocation since 2005. The advocacy arm of Greenpeace USA allocated 8.64 percent of its budget in 2003 and zero since. The education and research component of Greenpeace USA allocated 18.29 percent in 2003, 2.04 percent in 2004, and zero since. Greenpeace France has allocated more than 11 percent of its budget each year while Greenpeace Spain has allocated more than 8 percent. Both units continue to fund the GM campaign. One-way analysis of variance (ANOVA) was used to measure differences in means between the national EU and US Greenpeace units, the International unit, and Worldwide aggregate. The results are presented in Table 2.

Thus, our predictions that Greenpeace responds like a transnational corporation (locally responsive but globally coordinated) to local institutional pressure were supported. The European units allocated a greater percentage of their budget to the antiGM campaign than did the research and education component of Greenpeace USA Fund, except for a significant amount of spending on this campaign by Greenpeace USA Fund in 2003. This single-year surge suggests a brief attempt to sway public opinion in the US and thus shift the informal institutional environment toward opposing GMOs, rather than going after formal public policy institutions, as their counterparts did in the EU. Such an attempt would be consistent with the US formal institutional environment that does not include Greenpeace in the formal decision-making process. Alternatively, the increased spending by Greenpeace USA Fund on this campaign in 2003 and 2004 may have been a response to the allegations made by Public Interest Watch in 2003 that the fund was in violation of US tax law (National Review, 2003). The investigation lasted through 2004, when the allegations were cleared and Public Interest Watch was subsequently revealed to be funded by Exxon Mobile (Stecklow, 2006). Despite its 
apparent innocence in tax fraud, the fund may have felt pressured to spend more on this campaign to ensure that its innocence was clear to all. The data for Greenpeace USA Inc. (the advocacy arm of Greenpeace USA) in 2003 are consistent with our predictions, as the budget allocation was lower than that of the EU units. Since 2005, in the US Greenpeace has allocated none of its budget to the anti-GM campaign while the European units have continued to fund it.

Table 2 ANOVA results

\begin{tabular}{lccc}
\hline \multicolumn{1}{c}{ Units } & $\begin{array}{c}\text { Significantly } \\
\text { Different }\end{array}$ & $\boldsymbol{F}$ & F-critical, 5\% \\
\hline All & $\mathrm{Y}$ & 13.89404 & 2.437693 \\
International, World Wide & $\mathrm{N}$ & 1.320619 & 4.413873 \\
France, Spain & $\mathrm{Y}$ & 9.205904 & 4.60011 \\
World Wide, France & $\mathrm{N}$ & 0.015848 & 4.413873 \\
International, France & $\mathrm{N}$ & 3.520459 & 4.413873 \\
World Wide, Spain & $\mathrm{N}$ & 1.840238 & 4.667193 \\
International, Spain & $\mathrm{N}$ & 0.805852 & 4.667193 \\
World Wide, USA Inc. & $\mathrm{Y}$ & 28.4246 & 4.747225 \\
International, USA Inc. & $\mathrm{Y}$ & 37.41852 & 4.964603 \\
World Wide, USA Fund & $\mathrm{Y}$ & 8.999486 & 4.747225 \\
International, USA Fund & $\mathrm{Y}$ & 8.084787 & 4.964603 \\
France, USA Inc. & $\mathrm{Y}$ & 80.74717 & 4.60011 \\
Spain, USA Inc. & $\mathrm{Y}$ & 32.76855 & 4.964603 \\
France, USA Fund & $\mathrm{Y}$ & 16.95174 & 4.60011 \\
Spain, USA Fund & $\mathrm{Y}$ & 5.384215 & 4.964603 \\
\hline Note: & & &
\end{tabular}

Note:

- Greenpeace France allocated a significantly greater percentage of its resources to the antiGM campaign than did the Greenpeace units in the United States.

- Greenpeace Spain allocated a significantly greater percentage of its resources to the antiGM campaign than did the Greenpeace units in the United States.

- Both United States units of Greenpeace allocated a significantly smaller percentage of their resources to the anti-GM campaign than did Greenpeace International.

- Both United States units of Greenpeace allocated a significantly smaller percentage of their resources to the anti-GM campaign than did Greenpeace Worldwide.

- Greenpeace France allocated a greater percentage of its resources to the anti-GM campaign than did Greenpeace Spain. 


\section{Limitations}

A key limitation of our study was that the data came only from publicly available reports from Greenpeace itself. While the data supported our predictions, they are not sufficiently robust for us to consider the matter resolved. While Greenpeace has no reason to manipulate its data, it also has no reason to make sufficiently detailed information public to allow for more sophisticated analytic techniques, such as multivariate regression. We found that Greenpeace's resource allocation varies as a function of differences in institutional pressure, but future work using more detailed data could paint a more detailed picture. Because of the limited nature of the data, nothing more than a limited ANOVA test could be applied to examine the statistical significance of the differences we predicted rather than to test specific hypotheses. A quantitative research would be able to evaluate whether our findings can be applied beyond this case.

Another limitation of this study is that we have treated France and Spain as two states within the EU, disregarding formal differences between the two. While studies of differences among US states might similarly focus on cultural differences rather than formal institutional differences, for example, Alabama, New York, and Montana have very different cultures, US states all have similar formal institutions, with a governor, a legislature, and so on. The formal differences between France and Spain are more marked, since Spain is a constitutional monarchy with a parliament while France is a semi-presidential system without a monarch. We believe our findings still reflect considerable difference in informal institutions between the two nations, but we recognize that further study should try to disentangle the formal differences from the informal ones.

\section{CONCLUSION}

\section{Theoretical Contributions and Directions for Future Research}

We found in the case of Greenpeace that both formal and informal institutional environments affect NGO strategy in developed regions of the world, although since our findings are based on a single case, generalizations to other settings and situations should be made cautiously. Formal and informal institutional pressures in the region(s) studied might explain the findings from the developed world that are not consistent with theory (e.g., Davis, et al., 2009). As in the Greenpeace case, when neither informal nor formal institutional environments support a goal, organizations in those environments, 
both profit and non-profit, are best served pursuing other goals or finding other environments, even in developed nations.

The national units of Greenpeace in the two nations with similar formal institutional environments use strategies similar to those used by a unit with a significantly different formal institutional environment. Variations in their informal institutional environments, however, appear to lead to a significant difference between the strategies of the French and Spanish units. Context matters, and institutional pressure is not necessarily consistent in the developed world. While formal macropolitical structures have been shown to influence non-profit activity (Bloodgood et al., 2013), our research demonstrates that informal institutional pressures may be just as significant. Certainly, in the case of Greenpeace in United States, France, and Spain, formal and informal institutional variation coincided with non-profit strategy. Future studies should explore the interaction of formal macropolitical and micropolitical institutional forces and informal institutions, as this may reveal a more robust understanding of non-profit behavior.

Our study indicates that Greenpeace is a sophisticated organization consisting of a central coordinating body that organizes global campaigns co-determined by national organizations. Simultaneously, the national organizations determine their own local strategic campaigns constrained by the requirement to implement at least two of the centrally determined, yet co-determined, campaigns. This arrangement, which we discussed in greater detail earlier in the paper, appears ripe for further investigation of international, global, multidomestic, and transnational strategies (Bartlett \& Ghoshal, 2002). Greenpeace as an organization may represent the archetype transnational, an idealized MNE strategy of locally-focused initiatives that leverage global opportunities, which is quite elusive in the for-profit world (Rothaermel, 2013). Recent evidence (Nesbit \& Lam, 2014) have suggested that non-profits may have difficulty adopting new concepts. As such, both non-profits and for-profits have much to learn from how Greenpeace operates. Further research should include additional non-profits to ascertain strategic types and possible solutions for profit-oriented MNEs to compete in their quest for global integration and local responsiveness. Prior work on the different constraints affecting decisions of non-profits and for-profits (e.g., Hull \& Lio, 2006) has suggested that for-profits have an advantage over non-profits with respect to innovation, as the profit motive makes it easier for companies to pursue innovation to achieve desired outcome. However, while making a profit may help companies innovate, prioritizing non-financial goals may yield non-profit gains in pursuing a transnational strategy, such as in the case of Greenpeace. Without profits at stake, it may be easier to trust divisions in other parts of the world and understand how to pursue 
the same overall vision in the context of different institutional pressures at local levels. Further research in this area is needed.

We also hope to see more studies that examine the efficacy of non-profit organizational structures such as the transnational one we found. While our study shows that the structure of Greenpeace facilitates the responsiveness of the organization to national and regional institutional constructs, it does not address the effectiveness of those decisions. Rost and Graetzer's (2014) recent study of Catholic Orders provides a robust argument for the importance of structure in non-profits. A comparison of how non-profits with differing organizational structures approach national responsiveness may yield an understanding of organizational effectiveness.

Though our case study involved a single non-profit, it helps illuminate how institutional theory applies to non-profits in developed nations. Perhaps developed nations have not evolved in the same way, such that even if they are efficient, they are not equally efficient at all things or in the same ways (c.f., Minkov \& Hofstede, 2011). $\mathrm{Wu}$ and Ying (2016) suggested that there is a need to adapt to local institutional pressures in China, and we argue that this is true in all countries, which is why the transnational strategy has so much potential.

The social rationality approach in the EU and the scientific rationality approach in the US may affect the introduction of other new technologies, but the finding that institutional theory applies to all nations and regions regardless of development status means that institutional theory should be considered a universal theory (c.f., Peng et al., 2009). Although this study addressed the call (Peng et al., 2009) to study institutional theory in contexts outside those of emerging markets, more research is needed to better understand the applicability of institutional theory in developed economies and to understand specific institutional differences that have hitherto been overlooked.

One question that deserves further inquiry is whether "developed" economies can devolve to "developing" status. If the US's formal and informal institutions allow powerful corporations to push through regulations, making their products legal based on flimsy scientific evidence (Séralini et al., 2009), then the inefficiencies attributed to developing nations might reasonably be thought to apply to the US as well. Alternatively, perhaps the terms "developed" and "developing" economies are inappropriate, as the one implies having completed a journey or graduating from a process while the other implies an incompleteness that can only be perfected be becoming exactly like the "developed" nations. It is unreasonable to assume that "developed" nations are perfect either in themselves or serve as examples to others, particularly in light of our findings. 
Greenpeace might also have benefitted from understanding institutional nuances across nations when choosing which campaigns to support in which countries. Future studies might consider using the institution-based approach to build an integrating framework to help explain the MNE-non-profit relationship. It might also be worthwhile to examine how the international strategies of the MNEs most directly affected by Greenpeace compare in terms of environmental and financial performance. Given the emergence of new strategies among non-profits in opposition to hightechnology innovations (Luxmore \& Hull, 2011) and the near-textbook perfect application of the transnational strategy by Greenpeace, it would be interesting to see whether the more successful GMO companies have adopted similar international strategies.

This study showed that institutions affect strategic behavior but did not address tactical actions that might affect the influence of non-profit on markets. The actions of the research and education unit Greenpeace USA Fund suggest that non-profits may do more than represent the interests of social movements in the formal institutional dimension in that they may attempt to influence existing culture and normative beliefs, sometimes successfully. Despite the limiting formal institution framework in the US, Greenpeace US still allocated resources to the campaign. It is possible that Greenpeace USA chose to fund the anti-GM campaign due to its participation in Greenpeace International's global anti-GM campaign. Holtbrügge and Dögl (2012) argued that more multinational data on corporate environmental responsibility (CER) is needed. Our study responded to this call using the data collected from a multinational non-profit organization that encourages CER and underscores the importance of institutional pressures on its activities and by extension on CER in general. Future research into the institution-based approach as an analytical tool to understand the tactical behavior of non-profits should expand our understanding of their behavior and its implications.

\section{Practical Implications for Managers}

The strategic behavior of Greenpeace International and the European and USbased national units in their anti-GM campaigns supports the application of institutional theory in this case. The increasing importance of non-profits in the realm of international business (Burchell \& Cook, 2013; Doh \& Guay, 2006; Kourula \& Laasonen, 2010; Teegen et al., 2004; Vachani et al., 2009) means that researchers and managers need to better understand non-profits. Managers are increasingly required to engage non-profits and include them in their decision-making process (Burchell \& Cook, 2013; Levy, 2008). Institutional theory is a promising way to understand nonprofit strategic actions across multiple markets. As our study indicates, the national units of Greenpeace strategically allocate their resources to campaigns that they hope 
will have the greatest impact, given their specific institutional environments. For managers of firms such as Monsanto, the implications of our study are clear, suggesting that they can make more informed strategic decisions if they use institutional theory to predict the strategies of Greenpeace and similar non-profits operating across multiple markets.

\section{REFERENCES}

Almadi, M. M. (2016). The impact of contextualizing board structure on firm financial performance in an emerging market. Contemporary Management Research, 12(4), 409-434. https://doi.org/10.7903/cmr.15752

Al-Shammari, H. A. (2012). The effects of culture and institutional context on intercountry variance of outsourcing practices. Journal of Transnational Management, 17(3), 205-219.

https://doi.org/10.1080/15475778.2012.706700

Bartlett, C. A., \& Ghoshal, S. (2002). Managing across borders: The transnational solution. Boston: Harvard University Press.

https://doi.org/10.1007/978-1-137-28787-8_25

Berrone, P., Gelabert, L., Massa-Saluzzo, F., \& Rousseau, H. (2016). Understanding community dynamic in the study of grand challenges: How nonprofits, institutional actors, and the community fabric interact to influence income inequality. Academy of Management Journal, 59(6), 1940-1964. https://doi.org/10.5465/amj.2015.0746

Bloodgood, E. A., Tremblay-Boire, J., \& Prakash, A. (2013). National styles of NGO regulation. Nonprofit and Voluntary Sector Quarterly, 43(4), 716-736. https://doi.org/10.1177/0899764013481111

Burchell, J., \& Cook, J. (2013). Sleeping with the enemy? Strategic transformations in business-NGO relationships through stakeholder dialogue. Journal of Business Ethics, 113(3), 505-518. https://doi.org/10.1007/s10551-012-1319-1

Carraher, S. M., Welsh, D. H., \& Svilokos, A. (2016). Validation of a measure of social entrepreneurship. European Journal of International Management, 10(4), 386-402. https://doi.org/10.1504/ejim.2016.077421

Chen, Y. R., Yang, C., Hsu, S. M., \& Wang, Y. D. (2008). Entry mode choice in China's regional distribution markets: Institution vs. transaction costs perspectives. Industrial Marketing Management, 38(7), 702-713.

https://doi.org/10.1016/j. indmarman.2008.02.001 
Cheng, L. J., \& Liao, C. C. (2017). The drivers of entrepreneurial intention: The role of social capital and overconfidence. Contemporary Management Research, 13(2), 143-162. https://doi.org/10.7903/cmr.17589

Davis, J. A., Marino, L. D., Aaron, J. R., \& Tolbert, C. L. (2009). An examination of entrepreneurial orientation, environmental scanning, and market strategies of nonprofit and for-profit nursing home administrators. Nonprofit and Voluntary Sector Quarterly, 40(1), 197-211. https://doi.org/10.1177/0899764009351112

Davis, L. E., North, D. C. (1971). Institutional change and American economic growth. Cambridge, UK: Cambridge University Press.

https://doi.org/10.1017/cbo9780511561078

De Lange, D. E. (2016). Legitimation Strategies for Clean Technology Entrepreneurs Facing Institutional Voids in Emerging Economies. Journal of International Management. 22(4), 403-415. https://doi.org/10.1016/j.intman.2016.06.002

Doh, J. P., \& Guay, T. R. (2006). Corporate social responsibility, public policy, and NGO activism in Europe and the United States: An institutional-stakeholder perspective. Journal of Management Studies, 43(1), 47-73.

https://doi.org/10.1111/j.1467-6486.2006.00582.x

Eesley, C., Decelles, K. A., \& Lenox, M. (2016). Through the mud or in the boardroom: Examining activist types and their strategies in targeting firms for social change. Strategic Management Journal, 37(12), 2425-2440.

https://doi.org/10.1002/smj.2458

Finegold, D., Klossek, A., Nippa, M., \& Winkler. A-L. (2010). Explaining firm approaches to corporate social responsibility: Institutional environments and firm size. European Journal of International Management, 4(3), 213-233. https://doi.org/10.1504/ejim.2010.033001

Frumkin, P., \& Andre-Clark, A. (2000). When missions, markets, and politics collide: Values and strategy in the nonprofit human services. Nonprofit and Voluntary Sector Quarterly, 29(suppl. 1), 141-163.

https://doi.org/10.1177/0899764000291s007

Garrow, E. E., \& Hasenfeld, Y. (2012). Institutional logics, moral frames, and advocacy explaining the purpose of advocacy among nonprofit human-service organizations. Nonprofit and Voluntary Sector Quarterly, 43(1), 80-98.

https://doi.org/10.1177/0899764012468061

Greenpeace International. (2018). Retrieved from http://www.greenpeace.org /international/en/. Accessed 21 January 2018.

Greenpeace International. (1997). 1996 Annual Report. Retrieved from http://www.greenpeace.org/international/Global/international/planet-2/report/2006/11 /annual -report-1996.pdf. 
Guehlstorf, N. P., \& Hallstrom, L. K. (2005). The role of culture in risk regulations: A comparative case study of genetically modified corn in the United States of America and European Union. Environmental Science \& Policy, 8(4), 327-342. https://doi.org/10.1016/j.envsci.2005.04.007

Hiatt, S. R., \& Park, S. (2013). Lords of the harvest: Third-party influence and regulatory approval of genetically modified organisms. Academy of Management Journal, 56(4), 923-944. https://doi.org/10.5465/amj.2011.0128

Hillman, A., \& Keim, G. (1995). International variation in the business-government interface: Institutional and organizational considerations. Academy of Management Review, 20(1), 193-214. https://doi.org/10.2307/258892

Hinz, V., \& Ingerfurth, S. (2013). Does ownership matter under challenging conditions?: On the relationship between organizational entrepreneurship and performance in the healthcare sector. Public Management Review, 15(7), 969-991. https://doi.org/10.1080/14719037.2012.757348

Hitt, M. A., Ahlstrom, D., Dacin, M. T., Levitas, E., \& Svobodina, L. (2004). The institutional effects on strategic partner selection in transition economies: China vs. Russia. Organizational Science, 15(2), 173-185.

https://doi.org/10.1287/orsc.1030.0045

Holtbrügge, D., \& Dögl, C. (2012). How international is corporate environmental responsibility? A literature review. Journal of International Management, 18(2), 180-195. https://doi.org/10.1016/j.intman.2012.02.001

Hofstede Center. (2018). Retrieved from https://www.hofstede-insights.com/country-comparison/

Hull, C. E., \& Lio, B. H. (2006). Innovation in non-profit and for-profit organizations: Visionary, strategic, and financial considerations. Journal of Change Management, 6(1), 53-65.https://doi.org/10.1080/14697010500523418

Hull, C. E., \& Luxmore, S. R. (2007). Influencing the acceptance of innovation: a tale of two perspectives on genetically-modified organisms. International Journal of Business Strategy, 7(2), 12-17.

Ioannou, I., \& Serafeim, G. (2010). What drives corporate social performance?: International evidence from social, environmental and governance sources. Working Paper 11-016. Cambridge: Harvard Business School.

Isaac, G. E., \& Kerr, W. A. (2003). Genetically modified organisms at the World Trade Organization: A harvest of trouble. Journal of World Trade, 37(6), 1083-1095. 
Isaac, G. E., Perdikis, N., \& Kerr, W. A. (2004). Cracking export markets with genetically modified crops: what is the entry mode strategy? International Marketing Review, 21 (4/5), 536-548.

https://doi.org/10.1108/02651330410547180

Kourula, A. (2010). Corporate engagement with non-governmental organizations in different institutional contexts-A case study of a forest products company. Journal of World Business, 45(4), 395-404.

https://doi.org/10.1016/ j.jwb.2009.08.010

Kourula, A., \& Laasonen, S. (2009). Nongovernmental organizations in business and society, management, and international business research. Business and Society, 49(1), 35-67. https://doi.org/10.1177/0007650309345282

Kshetri, N. (2015). Success of crowd-based online technology in fundraising: An institutional perspective. Journal of International Management, 21(2), 100-116. https://doi.org/10.1016/j.intman.2015.03.004

Kysar, D. A. (2004). Preferences for processes: the process/product distinction and the regulation of consumer choice. Harvard Law Review, 118(2), 526-642. https://doi.org/10.2307/4093392

Legge, Jr., J. S., \& Durant, R. F. (2010). Public opinion, risk assessment and biotechnology: Lessons from attitudes toward genetically modified foods in the European Union. Review of Policy Research, 27(1), 59-76.

https://doi.org/ 10.1111/j.1541-1338.2009.00427.x

Levidow, L., Carr, S., \& Wield, D. (2005). European Union regulation of agribiotechnology: Precautionary links between science, expertise and policy. Science and Public Policy, 32(4), 261-276. https://doi.org/10.3152/147154305781779452

Levidow, L., Murphy, J., \& Carr, S. (2007). Recasting "Substantial Equivalence": Transatlantic governance of GM food. Science, Technology \& Human Values, 32(1), 26-64. https://doi.org/10.1177/0162243906293885

Levy, D. L. (2008). Political contestation in global production networks. Academy of Management Review, 33(4), 943-963. https://doi.org/10.5465/amr.2008.34422006

Lu, J., Xu, B., \& Liu, X. (2009). The effects of corporate governance and institutional environments on export behavior in emerging markets. Management International Review, 49(4), 455-478. https://doi.org/10.1007/s11575-009-0004-9

Luria, G., Cnaan, R. A. \& Boehm, A. (2015). National culture and prosocial behaviors: Results from 66 countries. Nonprofit and Voluntary Sector Quarterly, 44(5), 1041 1065. https://doi.org/10.1177/0899764014554456

Luxmore, S. R., \& Hull, C. E. (2010). Externalities and the six facets model of technology management: genetically modified organisms in agribusiness. International Journal of Innovation and Technology Management, 7, 19-36. 
https://doi.org/10.1142/s0219877010001799

Luxmore, S. R., \& Hull, C. E. (2011). Innovation and NGOs A framework of interaction.

The International Journal of Entrepreneurship and Innovation, 12(1), 17-27.

https://doi.org/10.1142/s0219877010001799

Minkov, M., \& Hofstede, G. (2011). The evolution of Hofstede's doctrine. Cross Cultural Management: An International Journal, 18(1), 10-20.

https://doi.org/ 10.1108/13527601111104269

Meyer, K. E., Estrin, S., Bhaumik, S. K., \& Peng, M. W. (2009). Institutions, resources, and entry strategies in emerging economies. Strategic Management Journal, 30 (1), 61-80. https://doi.org/10.1002/smj.720

National Review. (2003). Seeing Greenpeace. Retrieved from https://www.nationalreview.com/2003/10/seeing-greenpeace/

Nesbit, P. L., \& Lam, E. (2014). Cultural adaptability and organizational change: A case study of a social service organization in Hong Kong. Contemporary Management Research, 10(4), 303-324. https://doi.org/10.7903/cmr.12186

North, D. C. (1990). Institutions, institutional change, and economic performance. Cambridge, MA: Harvard University Press. https://doi.org/10.1017/cbo9780511808678.003

Nugroho, Y. (2011). Opening the black box: The adoption of innovations in the voluntary sector - The case of Indonesian civil society organisations. Research Policy, 40(5), 761-777. https://doi.org/10.1016/j.respol.2011.03.002

OEC (2018a). Spain. Retrieved from http://atlas.media.mit.edu/en/profile/country/esp/ OEC (2018b). France. Retrieved from http://atlas.media.mit.edu/en/profile/country/fra/ Parkhe, A. (2003). Institutional environments, institutional change and international alliances. Journal of International Management, 9(3), 305-316.

https://doi.org/ 10.1016/s1075-4253(03)00038-3

Peng, M. W. (2002). Towards an institution-based view of business strategy. Asia Pacific Journal of Management, 19(2-3), 251-267.

https://doi.org/10.1023/A:1016291702714

Peng, M. W. (2003). Institutional transitions and strategic choices. Academy of Management Review, 28(2), 275-296. https://doi.org/10.2307/30040713

Peng, M. W. (2014). Global business (3rd ed.). Cincinnati, Ohio: South-Western Thomson.

Peng, M. W., Sun, L. S., Pinkham, B., \& Chen, H. (2009). The institution-based view as a third leg for a strategy tripod. Academy of Management Perspectives, 23(3), 63-81. https://doi.org/10.5465/amp.2009.43479264 
Pope, J. A., Isely, E. S., \& Asamoa-Tutu, F. (2009). Developing a marketing strategy for nonprofit organizations: An exploratory study. Journal of Nonprofit \& Public Sector Marketing, 21(2), 184-201. https://doi.org/10.1080/10495140802529532

Ren, M., \& Jack, R. (2014). China's' steel hunger': A comparative analysis of SOE and NSOE internationalization motivations and attitudes towards risk. Contemporary Management Research, 10(4), 325-352. https://doi.org/10.7903/cmr.12484.

Rothaermel, F. T. (2013). Strategic management: Concepts and cases. New York, NY: McGraw-Hill Irwin.

Rost, K., \& Graetzer, G. (2014). Multinational organizations as rule-following bureaucracies - The example of Catholic orders. Journal of International Management, 20(3), 290-311. https://doi.org/10.1016/j.intman.2013.11.001

Runge, C. F., Bagnara, G-L., \& Jackson, L. A. (2001). Differing US and European perspectives on GMOs: Political, economic and cultural issues. Journal of International Law and Trade Policy, 2, 221-234.

Saigo, H. (2000). Agriculture biotechnology and the negotiation of the Biosafety Protocol. The Georgetown International Environmental Law Review, 12, 779-816.

Schrempf-Stirling, J., Palazzo, G., \& Phillips, R. A. (2016). Historic corporate social responsibility. Academy of Management Review, 41(4), 700-719. https://dx.doi.ord/10.5465/amr.2014.0137

Scott, W. R. (2008) Institutions and organizations: Ideas and interests. Los Angeles, CA: Sage.

Séralini, G. E., De Vendômois, J. S., Cellier, D., Sultan, C., Buiatti, M., Gallagher, L., Antoniou, M., \& Dronamraju, K. R. (2009). How subchronic and chronic health effects can be neglected for GMOs, pesticides or chemicals. International Journal of Biological Sciences, 5(5), 438-443. https://doi.org/10.7150/ijbs.5.438

Simon, H. A. (2013). Administrative behavior. (2013). New York: The Free Press.

Soule, E. (2003). Corporate strategy, government regulatory policy and NGO activism: The case of genetically modified crops. In J. Doh \& H. Teegen (Eds.). Globalization and NGOs: Transforming business, government and society (pp. 130-156). Westport, CT: Praeger.

Stecklow, Steve (2006-03-21). Did a group financed by Exxon prompt IRS to audit Greenpeace? The Wall Street Journal. Retrieved from http://www.wsj.com/articles/ SB114291044305003774.

Tang, Z., \& Hull, C. E. (2012). An investigation of entrepreneurial orientation, perceived environmental hostility, and strategy application among Chinese SMEs. Journal of Small Business Management, 50(1), 132-158.

https://doi.org/10.1111/j.1540-627x.2011.00347.x 
Tantawi, P. I., O’Shaughnessy, N. J., Gad, K. A., \& Ragheb, M. A. S. (2009). Green consciousness of consumers in a developing country: A study of Egyptian consumers. Contemporary Management Research, 5(1), 29-50. https://doi.org/10.7903/cmr.1149

Taysir, E. A., \& Taysir, N. K. (2012). Measuring effectiveness in non-profit organizations: An integration effort. Journal of Transnational Management, 17(3), 220-235. https://doi.org/10.1080/15475778.2012.706736

Teegen, H., Doh, J., \& Vachani, S. (2004). The importance of nongovernmental organizations (NGOs) in global governance and value creation: an international business research agenda. Journal of International Business Studies, 35(6), 463483. https://doi.org/10.1057/palgrave.jibs.8400112

Vachani, S., Doh, J., \& Teegen, H. (2009). NGOs' influence on MNEs' social development strategies in varying institutional contexts: A transaction cost perspective. International Business Review, 18(5), 446-456.

https://doi.org/ 10.1016/j.ibusrev.2009.05.002

Van Leeuwen, M. H. D. \& Wiepking, P. (2012). National campaigns for charitable causes: A literature review. Nonprofit and Voluntary Sector Quarterly, 42(2), 219240. https://doi.org/10.1177/0899764012467084

Van Schendelen, R. (2003). The GMO food arena in the EU (1998-2001). Journal of Public Affairs, 3(3), 225-231. https://doi.org/10.1002/pa.150

Wales, W. J., Shirokova, G., Sokolova, L., \& Stein, C. (2016). Entrepreneurial orientation in the emerging Russian regulatory context: The criticality of interpersonal relationships. European Journal of International Management, 10(3), 359-382. https://doi.org/10.1504/ejim.2016.076256

Wootliff, J., \& Deri, C. (2001). NGOs: The new super brands. Corporate Reputation Review, 4(2), 157-164. https://doi.org/10.1057/palgrave.crr.1540140

Wu, H., \& Ying, S. X. (2016). Realizing auditor independence in China: Insights from the local context. Contemporary Management Research, 12(2), 245-272. https://doi.org/10.7903/cmr.15201.

Zhou, J. Q., \& Peng, M. W. (2010). Relational exchanges versus arm's-length transactions during institutional transitions. Asia Pacific Journal of Management, 27(3), 355-370. https://doi.org/10.1007/s10490-009-9142-7 